\title{
Linguistic Hypertext in Contemporary Literary Discourse of the Mordva
}

(2012)

\author{
Serafima Panfilova \\ Mordovia State University \\ scully_ss@rambler.ru
}

According to the latest census of 2010, Mordvinians make up more than 750,000 of the Russian population. Though Mordvinians are the largest indigenous Finno-Ugric ethnos of Russia, historically, they are scattered over the Russian regions: ${ }^{1}$ Penza $(54,703)$, Nizhny Novgorod $(19,138)$, Orenburg $(38,682)$, Samara $(65,447)$, Tatarstan $(19,156)$, Ulyanovsk $(38,977)$, Moscow $(17,095)$, Bashkortostan $(20,300)$, Siberia $(65,650)$, Russian Far East $(29,265)$, as well as the former USSR republics, Ukraine $(9,331)$ and Kazakhstan $(8,031)$ being the SNA countries with the largest Mordvinian populations. In the 1990s, due to the fall of the 'Iron Curtain', there was an increase in Mordvinians' migration to Western countries, mostly to Estonia, Finland, and Latvia. As a result, currently only fewer than one third of Mordvinians $(333,112)$ live in Mordovia Republic, Russia. Thus, the problem of preserving national identity has arisen most acutely with the Mordvinians.

Language is one of the major aspects of ethnic self-identification, though in case of Mordvinians, it is most difficult to preserve, under the conditions of Russian's being the official language on the one hand and territorial disintegration of the Mordvinian people on the other. Various solutions have been suggested to the problem of maintaining Mordvinian languages in the diaspora. Particularly, literary texts (poetry, prose, drama) are considered to be very efficient in establishing dialogue between the scattered Mordvinian clusters and the center of Mordvinian culture (Mordovia Republic). Authentic fiction and poetry texts have great potential to compensate for the lack of live communication. In the diaspora, Mordvinians generally are surrounded by non-Mordvinian speakers; they have no native language environment in the territories they inhabit. Thus, there appears to be a good opportunity to slow down the assimilation processes of the Mordvinians, as literary texts help to develop sustainable interest in their native languages.

${ }^{1}$ This process started in the 17th century when Mordvinian territories were joined to Russia. According to Pavel Melnikov-Pechersky, a 19th century Russian ethnographer, the forced Christianization of the Mordva, being an important part of Russian policy in the region, caused Mordvinian migration to other, usually less explored, regions. At that time, generally, it was Siberia. Another reason for the Mordvinians' historical dispersion was territorial disintegration. Thus after joining Russia, the native Mordvinian territories were split up between four provinces. 


\section{Linguistic hypertext: theoretical and methodological reflections}

\subsection{Literary process of the Mordva: background information}

In general, Mordvinians are subdivided into two major ethnic subgroups: ${ }^{2}$ the Erzia, who speak the Erzian language, and the Moksha, who speak the Mokshan language. The languages have dialects: the Erzian dialects split into five types and the Mokshan ones into three. The two languages also have separate literary forms. The Erzian literary language is based on the Kozlov-Ardatov dialects (the eastern part of the Mordovia Republic, Russia), while the Mokshan literary language has developed out of the Krasnoslobodsk-Temnikov dialects (the western part of the Mordovia Republic, Russia). The literary Mordvinian languages were developed from the very beginning using the standard Russian Cyrillic alphabet. As the Erzian literary language was created in 1922 and the Mokshan in 1923, both languages only recently acquired their written forms (Feoktistov, 1976). A point should be made that before the October Revolution written sources in Mordvinian languages were mostly connected to religion and aimed at the dissemination of Christianity among the Mordvinians. ${ }^{3}$

Thus, the history of Mordvinian literature started in the 1920s with the first publications in periodicals. At that time the key Mordvinian literary magazines were established: Syatko magazine (published in Erzian since 1929) and Moksha magazine (published in Mokshan since 1928). As for non-periodical editions, the first samples of Mordvinian literary works were published either in the form of collections by author groups (e.g., Erzian pyesat, 1924 - a collection of Erzian plays by T. Vasilyev, E. Okin, and F. Chesnokov), or in the form of editions by individual authors (e.g. Liya kiyava [The Other Way], 1927 - a collection of short stories by Fyodor Chesnokov). Though the Mordvinian literary process has a relatively short history of about eighty years, the Mokshans and Erzians definitely succeeded in establishing and developing their own literary traditions. This statement can be supported by the fact that there exist samples of Mordvianian texts in all major literary genres: drama (e.g. plays Narodt lemsa and Shin styama by Grigory

\footnotetext{
${ }^{2}$ Apart from the Moksha and the Erzia, two more Mordvinian ethnic subgroups are distinguished: the Shoksha and the Karatays. However, these subgroups developed neither their own literary languages, nor their literary tradition. Consequently, we do not consider them in our study.

${ }^{3}$ Other written sources in the Mordvinian languages included grammar books (the first Mokshan grammar was published in 1838, and the first Erzian grammar was published 1839), dictionaries (about 600 Mordvinian words were included into the Comparative Dictionary of Languages and Dialects of the Russian Empire published in 1787 for the first time), and folklore works (first published in 1830).
} 
Merkushkin), poetry (e.g. verse novel Poksh ki langso umarina by Nikolay Kutorkin; numerous books of poems by Erzian poet Artur Moro), short story (e.g., collections of short stories, such as Kyazhi syava and Viren vaigyailkht by Vasily Viard), novel (e.g., Nardishe by Ilya Devin), epic novel (e.g., the trilogy Erzian tsyora by the classical Erzian novelist Kuzma Abramov). At present the national literary tradition continues with the names of Erzian poet Alexander Arapov, Erzian novelist Andrey Bryzhinsky, Mokshan playwright Alexander Pudin, etc.

Overall, the literary production of the Mordvinian people has proven to be sustainable and diverse. Though not a long one in terms of global standards, the national literary tradition was founded and developed successfully. In the course of its development, the tradition has revealed its peculiar features at various stages. Referring to the contemporary Mordvinian literary discourse, we should consider hypertextuality as one of its key characteristics.

\subsection{Hypertextuality Approaches and Concepts}

In this paper, we regard the phenomenon of hypertextuality as a type of intertextual relationship. ${ }^{4}$ Our study is based on the hypertext conception suggested by the French literary theorist Gérard Genette (1982). In Genette's theory the term 'hypertextuality' is used to refer to the type of relationships between fiction texts only, where one or more texts derive from the initial text by means of direct transformation or imitation. ${ }^{5}$ As a result, literary parodies and pastiches emerge. In this respect, he introduced two terms to describe hypertextual relationships. 'Hypotext' is used to refer to the initial literary text, while 'hypertext' means any new literary text derived from the initial one. In this framework, the central hypothesis can be summed up as follows: hypertextuality is a type of semantic interaction between literary texts, resulting in the emergence of new literary text(s) on the base of the initial one. The following example can demonstrate this type of hypertextual relationship. There is a world-famous best-selling fantasy novel Harry Potter by the English author J. K. Rowling. Similarly, there exists Tanya Grottera Russian fantasy novel series by Dmitry Yemets started in 2002. Tanya's story bears a certain resemblance to J. K. Rowling's world-famous Harry Potter. Like Harry, Tanya is an orphan who attends a school for young wizards. In this case, the initial text is Harry Potter (i.e., hypotext) and its literary clone is Tanya Grotter (i.e., hypertext).

4 Other types of intertextual relationships usually include intertextuality, paratextuality, metatextuality, and architextuality.

${ }^{5}$ Genette uses the French term 'se grefer' that means 'to branch off'. 
Genette's theory has been developed both in the framework of linguistics and literature studies. Currently the term 'hypertextuality' is applied to a wider range of phenomena. In terms of literary discourse, another type of hypertextual relationship arises between the initial literary text (hypotext) and the relevant non-literary texts derived (hypertexts). Taking this fact into consideration, the Russian linguist Nikolay Shekhtman has introduced the term 'linguistic hypertext' to refer to the nonliterary texts resulting from this type of interaction. Initially, he included notes to the literary text in the linguistic hypertext phenomenon (Shekhtman, 2005). Certainly there was a point in doing it in order to distinguish between linguistic hypertext and the other types of hypertext that exist, i.e. electronic and literary hypertexts.

A point should be made that the bulk of hypertext studies in linguistics are being carried out in the field of electronic hypertext. ${ }^{6}$ According to this approach, hypertext is closely connected to computer technologies, as the term was introduced by the American researcher V. Bush to refer to any text which cannot be printed on a conventional page (Bush, 1945). The concept of 'hypertext' resulted in numerous studies of electronic texts' organization structure, e.g. hyperlink system, electronic dictionary organization, Web-site structures, blog functioning, etc. Recently the Internet, being the main electronic environment, has acquired the status of one of the key notions in the contemporary hypertext studies. Currently the functioning of electronic hypertexts takes place mostly in the World Wide Web, which provides the proper realization of its intertextual correlation potential by means of hyperlinks.

With regard to linguistic (non-electronic) hypertext, this research area is a less-studied one within the framework of contemporary linguistics, while electronic hypertext is the focus of mainstream research. According to this approach, a hardcopy book can be regarded as a hypertextual structure. In fact, any literary text (a story, a novel, a play, etc.) is presented to the reader in the form of a book mostly. Actually, the book is inseparable from a literary text, and from the reader's point of view these two concepts are merged together. However, any hard-copy edition of a literary text usually includes other non-literary texts that can be regarded as linguistic hypertexts - e.g., notes, introduction, summary, praise, etc. In this framework, therefore, our task involves assessing correctly the variety of Mordvinian linguistic hypertexts and their functioning in contemporary Mordvinian literary discourse. In simple terms, we must be able to figure out the number of linguistic hypertexts used as well as their characteristics.

${ }^{6}$ See the works of Russian researchers Olga Dedova and Tatiana Ryazantseva. 


\section{Linguistic hypertext in Mordvinian literary discourse}

With these methodological reflections, we proceed to the analysis of relevant practical material. First, we should reveal the growth trend of Mordvinian linguistic hypertexts in recent decades. The earliest evidence of the phenomenon can be traced back to the 1980s. For instance, the first edition of the novel Nardishe [Green Grass] by the classical Mokshan writer Ilya Devin was published in 1969 and contained only the literary text without any linguistic hypertexts. On the contrary, a 1985 edition of the same author included a short summary of the foregoing literary texts.

(1) Илья Максимович Девинонь тя сборниксонза расскаст и очеркт. Синь эсост аф кунардонь ётай стака пингоньке, мзярда зярнясть войнань пушкатне, и тяниень эряфсь, кона пяшксе мирнай тевда, праздникта. Книгаса крхка мяльхть-арьсемат ломанть, эряфть колга, маряви ломанень ваймонь лямбось (Devin, 1985).

[This is a collection of Ilya Maximovich Devin's stories and essays. They tell about our recent hard past when the war guns roared. They also tell about our life now that is full of peaceful working days and holidays. The book presents some deep reflections about the man and his life goal.]

To compare this edition with the contemporary hard copy books of Mordvinian authors, it is obvious that all of the latter ones are accompanied by some type of linguistic hypertext or other. The various Mordvinian linguistics hypertexts demonstrate a certain constancy, including the following items: summary, introduction, and the author's biographical summary. Let's consider the items more closely.

\subsection{Summary as a type of linguistic hypertext}

At present a summary of the literary text is compulsory in Mordvinian literary hardcopy editions. It consists of three to five sentences (as a rule extended ones) and gives a short account of the forthcoming literary texts (examples 2, 3, 4 below). Practically, it means that the reader, having taken into consideration this type of linguistic hypertext, decides whether to start reading the literary text or not. Some summaries (3) are designed to interest the potential reader and make him read the literary text consequently. Thus, the informative function of linguistic hypertext is 
to present the topic of the literary text it refers to. As for its pragmatic function, linguistic hypertext is intended to arouse the reader's interest in the literary text.

(2) Содавикс эрзянь сёрмадеенть А. Д. Куторкин «Кочказь произведеният» васенце книгантень совасть «Покш ки лангсо умарина» романлсь ды «Ламзурь» поэмась. Романсонть невтевить Россиясо эрямопингень поки тевтне васенце револючиянь икастонть (1905 - 1907 иетнень), поэмасонть - 1743-1745 иетнень Нижегородской губерниянь Терюшевской волостень эрзятнень восстаниясь (Kutorkin, 2009).

[This book includes a novel 'Apple Tree Next to the Highway' and a poem 'Lamzur' by famous Erzian writer A. D. Kutorkin. The novel tells about the historical events of the first Russian revolution 1905-1907. The poem tells about the rebellion of Erzian people in the Nizhegorodskaya region, Teryushevskaya district in 1743-1745.]

(3) Те сборниксэнсть максовить эрзянь содавикс поэтэнть ды прозаикенть А. К. Мартиновонь колмо сехте содавикс произведениянзо: «Тетятнень киява» повестесь, «Монь ялгам» стихсэ повестесь ды «Розень кши» романось, конатнесэ авторсь невтинзе эрямосонть сехте неявикс тешкстнэнь.

«Тетятнень киява» повестьсэнть авторось сёрмады Гражданской войнадо мейле велесэ полавтовометнеде, «Монь ялгам» стихсэ повестьсэнть - Отечественной Ине войнадонть. Сёрмадеесть невти аволь ансяк фронтосо тюреманть, истя жо валосо тылсэ тевтненьгак. «Розень кши» романось алтазь мирной шкантень, сизьгнменце иетнестэ велесэ полавтовкстнэнень, зярдо эрямонтень кармасть совамо тевень ветямонь од койть-лувт (Martynov, 2012).

[The collection includes the most famous literary works of eminent Erzian poet and writer Alexander Martynov: the story 'Fathers' Way', the verse story 'My Friend', and the novel 'Rye Bread'. In these literary works the narration focuses on the periods of the country's history that had the greatest influence. In the novel 'Fathers' Way', the author describes the changes in rural life taking place after the Civil War. The verse story 'My Friend' tells about the Great Patriotic War. The author reports not only about the front line but also the life on the home front, namely the difficulties which the village people had to face during those hard wartime years. The novel 'Rye Bread' deals with the time of peace. It describes the 1970s, when there existed contradictions between the old ways of the rural economy and the new ones.] 
(4) Масторлангсо мезеяк арась вейке омбоиее ёнов допрок молиия. Мик кавтаськетнеяк вейкедест-вейкедест мейсэяк ды явовить. Истя эрси вечкемасояк. Эрьвань вечкемазо эсензэ, ансяк эсь тюс марто. Менель чирькень кодамо артовкссо артовкшныть сынь? Самай тень бажсияк авторось редямо ды невтеме книгасонть персонажтнэнь уияскаст вельде (Bryzhinsky, 2008).

[There is nothing identical in the world. This statement refers even to twins. The same is true with love. It is unique and original with every person. What colors do the feelings of love have? That is what the author is trying to depict, using the book's characters.]

\subsection{Introduction as a type of linguistic hypertext}

In fact, introduction is the oldest linguistic hypertext existing, as it was originally used in the first typography-printed literary texts. It was the first-printed edition of The Canterbury Tales by Geoffrey Chaucer. This historical event took place in London in 1483. The book included an introduction written by William Caxton, the editor. In the framework of Mordvinian literary discourse, this type of linguistic hypertext is quite common. Like the summary, it deals with the foregoing literary text but gives more information about it by going into details. Thus it normally includes an extended summary of the text, as well as its complete literary analysis. As for the Mordvinian introduction authors, they can be divided into two groups: 1) editors and critics (non-writers), and 2) other Mordvinian authors (usually the authoritative ones). When stating the introduction's functions in contemporary Mordvinian literary discourse, we should distinguish between the two general ones. On the one hand, it prepares the reader for the perception of the literary text by the interpretative means (preparatory function). On the other hand, it offers him the text assessment by giving professional views and opinions (assessing function).

Referring to the latest tendencies in Mordvinian literary discourse, we should consider the increase of biographical data inclusion into linguistic hypertexts. For example, introductions include more and more facts about the author's life. As for the constant elements, the author's family background and work experience prove to be stable items in contemporary Mordvinian introductions. We may even say that they have become integral parts of them. Traditionally, family background information includes some official facts from the author's biography--e.g., the place of birth, parents' names and occupations (5). Similarly, the introduction usually includes information about the author's education level, his workplaces in chronological order, and his literary career pursuit (6). On the other hand, the 
introduction may give the potential reader a unique opportunity to get acquainted with the author in a way, by presenting some moments from his private life such as his childhood dreams and wishes. Consequently, the reader can better understand the author's personality and imagine how he felt at certain periods of his life (7).

(5) а. Андрей Иванович - эрзянь содавикс писателенть Иван Сергеевич Брыюинскоень покш цёразо (Bryzhinsky, 2008, 3).

[Andrey Ivanovich is the elder son of famous Erzian writer Ivan Sergeyevich Bryzhinsky.]

b. Шачсь 1950-ияе кизонь 20-ие ноябрьста Инсарскяй райононь Адаж велеса. Тядянзя-алянза покодсть колхозса (Mishanina, 2002, 5).

[She (the writer) was born on 20 November 1950 in Insarsky district, Adaj village. Both her mother and father worked on the collective farm.]

с. Куторкинтнэнь семияст покшоль, важодемань вечкиияль. Дмитрий Тимофеевич ды Наталья Ивановна вишкапингэстэ саезб тонавтсть эйкакшост стакачиде а пелеме. Истямо ульнесть сынсь.

Наталья Ивановна ветясь кудоютконь, Дмитрий Тимофеевич - паксянь тевтнень. Арасель истямо тев, кона а теевиль Дмитрий Тимофеевичнень. Сон маштыль сокамо-видеме, кудонь чапомо, кузнииясо кини марто котьмамо. Теньс тонавтынзе иёранзояк. А. Д. Куторкин се шкастонть уш тонадокшнось чапомо, аритонь керсеме, лазонь пилямо, лишмень кильдеме (Kutorkin, 2009, 7).

[The future writer's parents were a very united and devoted family. Dmitry Timofeyevich (the father) and Natalia Ivanovna (the mother) brought up their children by teaching them to overcome difficulties. Their son took after them. Natalia Ivanovna was a housewife. Dmitry Timofeyevich mastered a number of crafts: ploughing, woodworking, blacksmith's work. He taught his son all these crafts. In his childhood, the future writer Andrey Kutorkin took up woodworking and mastered it.]

(6) а. Кемзисеме кизоса мяльсонза сон тусь тоза ялгазон мархта «Амерсталь» заводть строяма. Комсомолсь кучезе. Кода тоса работасть, кода строязь «Амерсталь» заводть, кода эрясть, Илья Кишняков лама кизода меле азондозе «Вешендьса эсь тяштезень» и «Монь таштезе - менельсь» романонзон эса (Kishnyakov, 2012, 5).

[When he (the writer) was 17 years old, he left home and went to build the Amerstal plant with some friends. He joined the Komsomol youth organization. 
Many years after that Ilya Kishnyakov revealed his experience as a plant builder in two novels of his: 'Searching for My Star' and 'My Star Is in the Sky'.]

b. Теде мейле важдось «Ленинэнь киява» да «Эрзянь коммуна» газетатнень редакииясо. 1958 иестэсаезь 1963 ульнесь «Сурань толт» журналонь прявт редакторокс, 1964-1971 иетнестэ - МАССР-нь Писателень союзонь Правлениянь правтокс (Martynov, 2012, 5).

[Since 1958, he worked at Leninen Kiyava newspaper and Erzian Kommuna newspaper. In 1963, he became the editor-in-chief of Suran' Tolt magazine. From 1964 to 1971 he was the head of the Mordvinian Writers Union.]

с. Работась редакторс Мордовскяй книжнай издательстваса прозонь отделань вятикс (1973), сямольде ответсвеннай секретарькс «Мокша» журналаса (1974-1994). 2000-це кизоть самс ульсь литературань и кялень коряс консультантокс Мокшэрьзянь национальнай театраса (Mishanina, 2002, 5).

[She worked as a prose editor in the Mordovian Publishing House (1973). Then she was the executive secretary of the Moksha journal (1974-1994). Since the year 2000 she has been a literature and language advisor for the Mordvinian National Theatre.]

d. Шачсь Максим Афанасьевич 1913 кизонь 10 февральста Ковылкинскяй райононь Керата мокшень велеса. Тонафнесь васенда эсь велень школаса, сяда меле Саранскяй педтехникумса (1931). 1939 кизоня заочна аделазе Мокшэрзянь педагогическяй институтть (Beban, 2009, 6)

[Maxim Afansyevich was born on 10 February 1913 in Mokshan village of Kerata, Kovylkinsky district. First he studied in the village school. Then he went to Saransk and graduated from Saransk Teacher's College in 1931. After that he studied part-time in the Mordvinian Pedagogical Institute and graduated from it in 1939.]

е. Шумордазе эсь университетсонк историко-филологическяй факультетть. Студентокс тяшнесь «Мокшень правдав», ульсь редакторкс факультетонь стенгазетаса...Тонафенсь аспирантураса литературань секторса (Kuznetsov, 2005, 7)

[He entered the University to study at the History and Philology Department. He was the editor of the department's student newspaper and a freelance writer for Mokshen Pravda newspaper...He was a graduate student of literature.] 
f. A мзярда 1968-иее кизоня республикань Писателень союзсь кучсь Москуву А. М. Горькаень лемса литературнай институту тонафнема мокшень и эрзянь цеерат и стирьхть, ётксостоль и Валентина Мишанинась, кона ся кизоня вчёк аделазе школать (Mishanina, 2002, 5) [And when in 1968 the Writers' Union of Mordovia Republic called for Mordvinian young girls and guys willing to study at the Moscow Literary Institute named after A. M. Gorky, Valentina Mishanina, who finished school in the same year, heeded the call and became a student at the Institute.]

(7) а. Кишняков Ильянди кемгафтува кизоль, мзярда сон, Алякс велень иёрась, няезе менельса кожфонь шарть, кона лийсь Москуть ширде....Тя ульсь 1934 кизоня....А менельса лиендсть ИЛ самолётт. Авиаконструкторть Сергей Владимирович Ильюшинонь лемоч лач содафоль кода марнек странасонк, станя и Аляксса. Кадошкинскяй райононь эряйхне аф весть кочксезь Ильюшинонь депутатокс и СССР-нь верховнай Совету. Сонь портретои эрь кудть стенасоль. Кодама иеерань ашель мялец арамс лётчикокс! (Kishnyakov, 2012, 5).

[When Ilya Kishnyakov was a 12-year-old boy from Alyaks village, for the first time he saw a balloon with people on it in the sky that was flying from Moscow... It was the year 1934. The first type of IL aircraft had been built. The aircraft was given its name after Sergey Vladimirovich Ilyushin, the aircraft designer. His name was a well-known name in Alyaks village, as he was the deputy, representing Kadoshkinsky district and Alyaks village in the Supreme Soviet in Moscow. His portrait was in the house of the future writer Ilya Kishnyakov. So it was no wonder that the boy wanted to be a pilot.]

b. 80 кизода инголе, 26 майста Атерень аймакса, Кямал велеса, шачсь иёраня - сай пингонь поэтсь Александр Малькин. Шабакс тейнза мярьгольхть Сандроня (Mal'kin, 2003, 5)

[Eighty years ago, on 26 May in Kyashal future Mordvinian poet Alexander Malkin was born. As a child, people used to call him Sandronya.]

\subsection{Author's biography as a type of hypertext}

The examples above demonstrate an acute interest in the author's personality in the framework of Mordvinian literary discourse of the present. This tendency resulted in to the appearance of a new type of linguistic hypertext. Thus, the author's biographical summary as a type of linguistic hypertext was started to be included in 
Mordvinian literary texts' editions at the beginning of the 21 st century. Unlike an introduction, it does not give a detailed account of the writer's life, comprising his childhood, adolescence, mature years, and senior years. Limited in space by no more than two paragraphs, the biographical summary gives the reader only key points of the author's life (8). Consequently, the reader does not have to study a longer introduction, searching for scattered biographical data. He has an opportunity to imagine the author as a real person at a glimpse. Trying to figure out the function of the biographical summary as a type of linguistic hypertext, we may state it as identifying. Having taking it into account, the potential reader identifies the author as a representative of some culture straight away.

Lexical analysis of the author's biography, considered as a hypertext, has revealed proper names to be its basic constituent element, due to their ample quantity. In accord with this, the five most frequently used classes of proper names are distinguished in Mordvinian author's biography: personal names (author's full name), place names (villages, cities, and countries that the author is connected to in some way), organization names (author's workplaces and educational institutions where he studied), and names of literary works (the titles of the author's most important achievements in the literary world). The following examples illustrate this statement adequately and clearly.

(8) а. Александр Васильевич Арапов чачсь 1959 иень ноябрянь 1-иее чистэ Дубёнской райононь Кенде велестэ. 1977 иестэ прядызе Кобалень школанть, 1983 иестэ - М. В. Ломоносов лемсэ МГУ-нь журналистикань факультетэнть. 1985 иестэ саезь роботь «Сятко» журналонь редакциясо. Россиянь Писателень союзонь член. Мордкизэсь нолдынзе поэзиянь колмо книганзо: «Вайгель» (1990), «Вальма» (1992), «Взмах» (2001). Стихензэ совасть вейсэнь сборникс, конат лиссть Саранск, Самара, Санкт-Петербург, Москов, Хельсинки, Будапешт, Таллин оштнэсэ. «Литературная Россия» газетань лауреат (2000). Ютко шкасто седи гитарасо, ладси морот эсь стихензэ лангс (Arapov, 2006). [Alexander Vasilyevich Arapov was born on the 1st of November, 1959, in a village of Dubensky district. He finished school in 1977. In 1983 he entered Moscow's Lomonosov State University, Journalism Department. In 1985 he started working for Syatko magazine. He joined the Russian Writers' Society. He wrote three books of poems (in the Erzian language): Voice (1990), Window (1992), Flapping (2001). His verses were published in Saransk, Samara, SaintPetersburg, Moscow, Helsinki, Budapest, and Tallinn. He received an award from the Literaturnaya Rossiya newspaper in 2000 . He played guitar very well and could sing his verses to music.] 
b. Более пятнадиати лет в Мордовской литературе известно имя поэта и прозаика Матюшкина Федора Петровича. Его стихи и рассказы печатаются в журнале «Мокша» и газете «Мокшень правда», находят широкий отклику уитателей, их своеобразную оригинальность и высокие художественные достоинства не раз отмечали критики.

Федор Матюшкин - человек рабочей закалки, много лет проработал $в$ рабочих коллективах, в тяжелье 1996-2003 г2. на заводе «Резинотехника» начальником цеха. Его рассказы и очерки о людях труда - это летопись сегодняшней действительности с ее сложнейтими проблемами и поиском путей их решения.

Федор Матюшкин третий год работает в редакиии журнала «Мокша» и вносит заметный вклад в творческую деятельность редакиии. Подготовил рукопись своих стихов и рассказов. Первая книга его литературных произведений представит читателю его творчество более полно (Matyushkin, 2012, 249).

[Mordvinian literature has known the name of Fyodor Matyushkin for more than fifteen years. His verses and stories are published in Moksha magazine and Mokshen pravda newspaper. His literary works are appreciated by both readers and critics for their unique and original nature. Fyodor Matyushkin comes from the working class. He used to be an industrial worker at several plants and factories. During the hard years of 1996-2003, he was appointed a superintendent at Rezinotekhnika plant. Consequently, his stories and essays tell about workers. His literary works make a chronicle of our reality today with its most complex problems, and seek ways to solve them. For three years Fyoodor Matyushkin has been on the staff of Moksha magazine. And his contribution to the editorial activity is quite considerable. He prepared his verses and stories for publication. This is the first book of his that will present his literary works to the readers more completely.]

с. Михаил Лукьянович Сайгин шачсь 1913 кизонь декабрьть 21-це шистонза Ковылкинскяй райононь Ёжка велеса. Родной велесонза тонафнесь школаса. Сяда меле сон тонафнесь Саранск, Горький, Моску ошса. Михаил Сайгин ушедсь рана сёрмадома. Сон нолдась лама повестень и азксонь сборник. 1974-це и сяда мельдень кизоста лиссть "Давол», «Крхка унккст», «Лямбе кожф», «Стака паваз» романонза. Михаил Лукьянович Мордовия Республикань заслуженнай, народнай писатель. Сон эряй Саранск ошса (Saigin, 2005).

[Mikhail Lukyanovich Saigin was born on 21 December 1913 in the village of Yezhovka, Kovylkinsky district. He went to school in his home village. After school he studied in Saransk, Gorky and Moscow. He started writing in his 
youth. He wrote many stories and a collection of fairy tales. Starting in 1974, the following novels of his have been published: Hurricane; Deep Roots; Warm Wind; Hard Happiness. Mikhail Lukyanovich was given the title of Honorary Writer of the Mordovia Republic. At present he lives in Saransk.]

\section{Conclusion}

To sum up our abovementioned considerations, as well as the potential of the examples demonstrated, we conclude that the role of linguistic hypertext in Mordvinian literary discourse is increasingly important at present, when compared with the situation in the 1970s and 1980s. Currently, there exist more types of linguistic hypertext functioning actively in the framework of contemporary Mordvinian literary production. In this connection we should point out a considerable growth of personal information included in linguistic hypertexts.

This implies that readers are really interested in the author as a real person. This fact reflects the anthropocentric paradigm in action, resulting in the humanization of modern society. In our opinion this tendency in Mordvinian literary discourse benefits the preservation of Mordvinian languages and cultural identity. The population settlement pattern of the Mordva makes authentic literary texts a good means of keeping in touch with Mordvinian diasporas around Russia and abroad. Linguistic hypertexts (introductions, summaries, biographical summaries) enhance this process by identifying the author and book in the context of the Mordvinian world. Consequently, the reader starts seeing the author as a real-life Mordvinian native-speaker and has an opportunity to get immersed in the Mokshan or Erzian language even from a great distance.

\section{References}

Arapov, Alexander. (2006) Meile. Saransk: Mordovian Publishing House.

Beban, M. A. (2009) Selected works (2 Vols.) Vol. 1. Stikht, basnyat, singoryamant, liya kyalsta yotaftfonza, poemat I antsai poyemanyat, sonett. Saransk: Mordovian Publishing House.

Bryzhinsky, Andrey. (2008) Vechkeman' tol potso: roman, povest', yovtnemat. Saransk: Mordovian Publishing House. 
Devin, Ilya (1985) Kosa kelun' shachemanyats. Saransk: Mordovian Publishing House.

Feoktistov, A. P. (1976) Ocherki po istorii formirovaniya mordovskikh pismennykh literaturnykh yazykov. Moscow.

Genette, Gerard (1982) Palimpsestes: la littérature au second degré. Paris: Ed. du Seuil.

Kishnyakov, I. P. (2012) Selected works (2 Vols.). Vol. 1. Azkst, povestt', roman. Saransk: Mordovian Publishing House.

Kutorkin, A. D. (2009) Selected works (2 Vols.). Vol. 2. Saransk: Mordovian Publishing House.

Kuznetsov, Yuri. (2005) Selected works (2 Vols.). Vol. 2. Azkst. Saransk: Mordovian Publishing House.

Mal'kin, Alexander. (2003) Selected works: Stikht i poemat. Saransk: Mordovian Publishing House.

Martynov, A. K. (2012) Selected works: Povest' dy roman. Saransk: Mordovian Publishing House.

Mishanina, Valentina. (2003) Val'maftoma kud. Saransk: Mordovian Publishing House.

Saigin, Mikhail. (2005) Od yalgat: azkst i yofkst. Saransk: Mordovian Publishing House.

Shekhtman, N. A. (2005) Ponimaniye rechevogo proizvedeniya i gipertext. Orenburg. 